\title{
Analysis of the objectives of physical education in schools in Algeria and their perception by teachers and students
}

\author{
Tarek Saker (1), Nabil Kerfes (2), Marc Cloes (3) \\ (1), (2). Laboratory of STAPS, Algiers 3 University, Algeria \\ (3). University of Liege, Belgium
}

\begin{abstract}
In the education system, the teaching of physical education is considered as an activity rather than a formalized intellectual activity. As a result, the perception of the pedagogical relationship actors in this field it is not always favorable, especially in Western countries. No data are currently available on this subject in Algeria. The goal of our research is to fill this gap. We proposed to 142 physical education teachers and 464 students in secondary and middle schools in the Algiers region to complete questionnaires to collect their representations with respect to physical education. We based on closed questions (Likert scale with four levels). In addition, an open question was included in the questionnaire for teachers. In this case a content analysis allowed us to classify the responses into a system of categories (\% agree intra-analyst $93.3 \%$ ). Among the results, we will retain that: (1) the representation of the majority of teachers to comply with official guidelines ; (2) physical education teachers mainly consider the status of physical education as "lower" than other school subjects ; (3) physical education is well appreciated by all students subject in school, (4) representations of actors pedagogical relationship differ between the Algerian situation and that of European countries.
\end{abstract}

Key Words: Objectives of $P$ E, perception, teachers, students.

\section{Introduction}

This article aims to identify the objectives of physical education in schools in Algeria and to compare their perceptions by teachers and students. Our concern lies in the fact that, from a methodological point of view, the physical education teacher poses a real problem. In fact, being considered as a formalization activity rather than as an intellectual activity, teacher training provided in physical education, in terms of knowledge, skills, life skills and analytical skills, do not have the same outcome as other so-called storage materials and scientific materials. This was highlighted by Arnaud ( 1983) : "Physical education through an identity crisis . She is torn between different designs, scattered in various techniques, invaded by sport or confused with it, and it seems harder than ever to know what are its aims. In short, it is looking for its identity " (p. 13). This specificity is a problem of perception about the objectives it is supposed to continue. This includes teachers and their perception of the material as well as taught often consider physical education as a complement to training promoting, among other things, integration into adult life.

Also interested in the evolution of the position of the body in French pedagogy, Thibault (1977) indicates that "the body was first seen as an instrument of war and was in turn accepted, obscured, reinstated and quartered "( p.17). In the same vein, Thomas (1982) distinguishes four streams based on the objectives assigned to physical education and sport in time in France: sports, military, medical and educational. «Mingling more or less, they will each, known through the centuries their vicissitudes «(Thomas, 1982, p. 9).

In 1962, the date of recovery of national sovereignty, Algeria inherited colonial education system. It was not until 1970 that Algeria has given birth to a first educational project that was integrated physical education. This project highlights the importance of physical education in the development process of Algerian society and you can read the definition currently in physical education: "The physical education is an education system integrated in the overall education system, obeying the purposes of this preliminary value through its own contributions, the formation of man, citizen and worker ensure their harmonious development of the society and the nation " ( Official Instruction, 1970, p. 6).

However, it is not our intention to discuss here the history of the Algerian physical education, the panel is not subject to our problem. We note only that the search for unity and coherence, physical education has struggled to develop on several fronts.

In this article, we are interested in the first place and overall analysis of the objectives of physical education. As a reminder, these are listed in a series of official texts.

A number of issues inherent in this aspect must indeed be raised:

$>$ What role physical education she occupies in the Algerian education system?

What is the main objective of physical education in the chief actors in the pedagogical relationship?

$>$ How do they perceive the latter the status of physical education? 
Perception is a complex phenomenon involving the mind and the result is reflected in terms of performances, so it is an identification of the teaching profession in physical education teacher by the problem itself, is seeking and reflecting on his role in the educational system and the objectives to be achieved in physical education. It is therefore appropriate to better define the image that teachers have of their discipline and their profession.

1see:

- Ministry of Youth and Sports (1995). Ordinance 95-09. Algeria.

- Ministry of Youth and Sports (1970). Official instructions. Algiers: Organization of Teaching Physical Education.

- Ministry of National Education (1976). Official Bulletin of National Education. Algeria.

- Ministry of National Education (1996). Algeria: Objectives of Physical Education in Teaching middle and secondary.

In addition, the centrality of students in the learning processes because of their representations of the activity a determining factor to explain their attitudes and behaviors in physical education classes.

\section{Objectives}

To try to answer these questions, we affect a survey in Algerian schools to analyze:

$\checkmark$ The perception of teachers towards the objectives of the material of which they are responsible.

$\checkmark$ Students' attitudes towards the school discipline.

$\checkmark$ Objectives they assign him.

$\checkmark$ Their perception of sports competence.

$\checkmark$ Style living.

\section{Materials and Methods}

3.1. Subjects: To achieve our research goals, field work was necessary. Select a representative sample thus proved crucial and we tried to meet a sufficient number of subjects. The sample of 142 teachers and 464 students (Table 1). Of the 142 teachers, a majority was male, as is the case in the education system of our country. Among students, the gender distribution is very balanced. The slight difference recorded in the upper classes seems normal with respect to the distribution of students in the same population.

Table 1. Presentation population

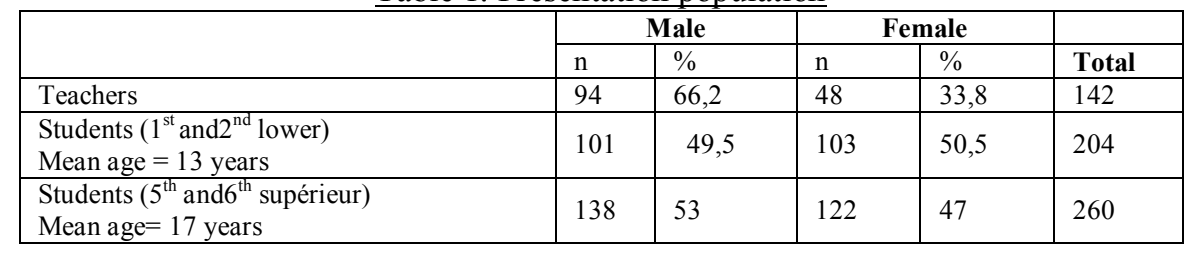

3.2. Instruments; A questionnaire was developed for each population. Both instruments include open questions and closed questions. Most private occasions in the student questionnaire questions based tools developed. tested and used by researchers at the Higher Institute of Physical Education and Physiotherapy, University of Liège.. .. Closed questions consist primarily of Likert scales in four points to determine the degree of agreement or importance that subjects grant proposals.

For teachers. The questionnaire contains 17 questions. In this article, we have chosen to focus on the responses to two of them. We focus here on the objectives of education. First,on the teacher's perception of his status and matter on the other. The questions are presented in Table 2.

Table 2: Questions to physical education teachers who were treated in this study

Question 1: What are the goals that you attribute to physical education? Question 2: In your opinion, in general and in relation to other matters, the status of physical education is it? (Significantly higher - Slightly higher - Below - Significantly lower)

The answers to question 1 were classified into several inductively categories. All items that we identified were classified into categories: health, fitness, technical and tactical, integration, education, active and fun students. The questionnaire developed to collect the opinions of the students are 19 issues. We have chosen to present here the results for six of them. They focus on the affective and cognitive components of students' attitudes toward school and physical education classes, their perceptions of the physical education teacher and daily sports activities (table 3 ). 
Table 3: Questions to students who have treated in this study

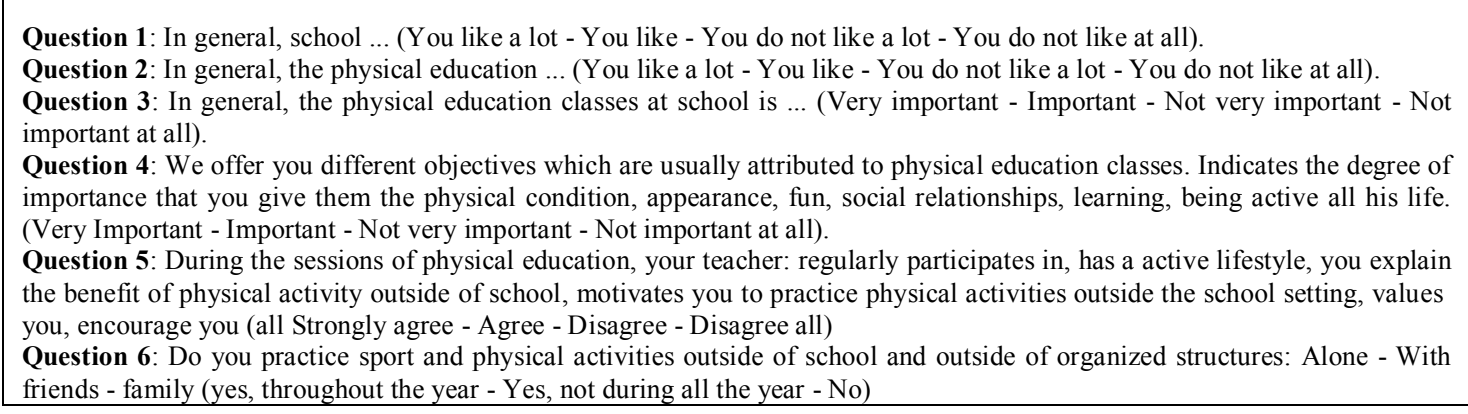

The questionnaires were collected in March to May 2006. Teachers were contacted by telephone to schedule an appointment. Teachers preferred to take the time to complete the questionnaire others responded immediately. a total of 142 teachers contacted on $160(88.8 \%)$ who completed the questionnaire is an excellent rate of return. Students were asked in the context of physical education lessons. thanks to the collaboration of seven schools in the Algiers region chosen to represent the different educational contexts. The first author visited the site to collect the more rigorous it is material data. To guarantee the reliability of responses. we systematically presented the goal of our research focusing on the anonymity of responses and highlighting the importance of honesty recent. This procedure generally lasted 20 to 30 minutes per class.

3.3. Data processing: During the procedure of data processing we coded the responses into a computer data base (Excel). The coding was based on the transformation of responses values ("1" to "disagree at all" or "not important at all" to "4" to "Strongly agree" or "very important" ). The statistical treatment was made using Statistica 7.1 software.. .... We used the test to compare two percentages and the chi-square test. allowing efficient comparison between subgroups of subjects.

\section{Results and Discussion}

We will describe the main ideas that emerge from the analysis. successively addressing the opinion of teachers and those of students. When possible. we cross the data to check if they are confirmed or not.

\subsection{First step: teachers}

The topics covered include (1) the aims and objectives of physical education and (2) perceptions of the physical education teacher regarding the status of their discipline.

\subsubsection{Aims and objectives of physical education}

Table 4, we can see that the development of physical fitness is identified as the main mission of teaching physical education teachers by the Algerian. This proves directly in line with the priorities established by education authorities (Ministry of Youth and Sports, 1995 Ministry of National Education, 1996). This role is very important in a society who must fight against a rise of inactivity. That teachers assign priority to this task should involve their course they choose activities and teaching methods focus on practical performance (programming cycles endurance or strength training, use of standards-based assessments scales performance ...). In the absence of objective data, we can not confirm that the practice mirrors that of practitioners.

The social aspect of physical education ("Mutual") occupies the second place and was mentioned by a third of teachers. This finding is very interesting because it highlights the share that teachers assign to education.

The skill development is the third objective of physical education. This finding heckled us in the sense that the acquisition of specific actions is the basis of the discipline: the development of motor skills. We believe that the emphasis currently sport development tends to be reduced compared to that given to maintaining basic physical qualities of students in a society that is increasingly sedentary.

Health is mentioned by two teachers out of 10 . Contrary to what is generally observed in Western countries where physical education is considered the cornerstone of health education (fight against physical inactivity and obesity, including - Pate et al, 2006), Algerian teachers do not seem to have integrated this design.

Education is the fifth goal. This indicates that teachers finally would give little attention to the term "education" associated with the name of their discipline.

Encourage students to be active can be understood in two ways: either ensure that students move during the course, a frequently recommended by trainers objective is prompted students to adopt an active lifestyle all throughout their life. This last objective is playing an increasingly important in international guidelines (Tappe \& Burgeson, 2004) and is logically the number one physical educators should logically 
provide students with every opportunity to develop the skills needed to become a priority citizens capable of managing their physical and motor life when they leave school. In this case, it is surprising that only 10 teachers mentioned this, emphasizing the need for an awareness campaign of the Algerian educational community about it.

Finally, the fun is only mentioned by $3 \%$ of teachers, particularly surprising result in light of the data available in the international literature (Interuniversity Research Group, 2003) and principles of pedagogy motivations, based on the pleasure of students (Florence, Brunelle \& Carlier, 1998). It is possible that our teachers would favor sports rather than negotiation with students is the lot of Western teachers rigor.

Table 4. Objectives allocated to physical education teachers.Comparison by gender (\%)

\begin{tabular}{|l|l|l|l|}
\hline Objectives PE & All & Men & Women \\
\hline fitness & 71 & 67,7 & 74,2 \\
\hline Mutual aid & 33 & 39,7 & 22,9 \\
\hline Tecnical and tactical & 31 & 26,6 & 41,7 \\
\hline Health & 21 & 13,8 & 28,4 \\
\hline Education & 16 & 16 & 16,7 \\
\hline Active students & 10 & 14,9 & 0 \\
\hline Fun & 3 & 0 & 10,9 \\
\hline
\end{tabular}

These results show that the objectives of physical education in Algeria are more focused on the sporting aspects. This view differs quite radically from that usually obtained in European countries, for example, in the French Community of Belgium. In this region, it appears that the texts are more appropriate to the needs of modern society in the sense that the legislature places particular emphasis on health.

This should especially be related to problems of obesity or cardiovascular diseases that are recorded in Western countries (WHO, 2006).

However, teachers' responses correspond fairly directly to the official guidelines. It would be interesting to check if they are sufficiently in line with the real needs of today's society. The comparison between the sex showed us that there was a significant difference in the importance attached to health $(\mathrm{p}=$ $0.001)$, technical and tactical development $(p=0.002)$ and mutual $(p=0,05)$.

\section{1. 2. Status of physical education teacher and his perception towards the material}

More than 7 out of 10 teachers believe that their discipline is considered inferior to other school subjects (Figure 1). This proportion reflects the existence of discomfort in physical educators. It is also highlighted in many other countries, including Western, stressing the need to systematically highlight the report of our discipline to limit the simplistic representations.

Comparison by gender shows that women are significantly more sensitive to this than men $(p=0.002)$. Combined with a "leisure" activity picture, status of women in a culture where they have difficulties to develop helps to understand this difference.

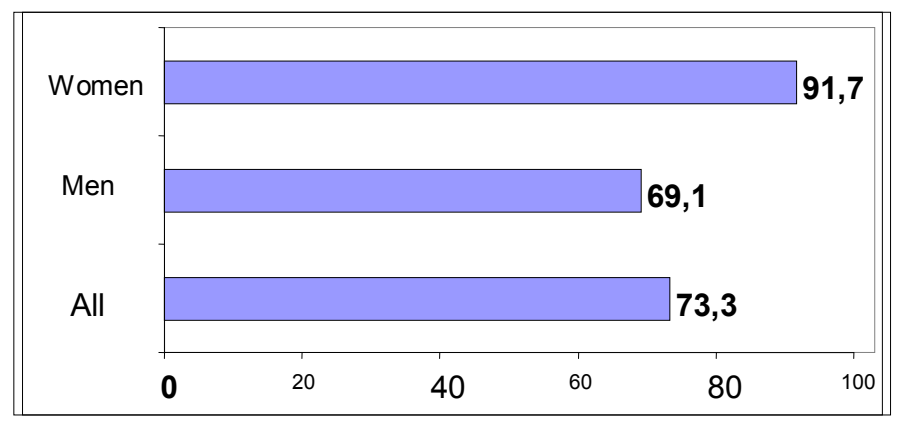

Figure 1. Proportions of teachers considering the status of physical education as inferior to that of other school subjects (\%)

This observation from the results obtained is very surprising considering the presence of the courses in the global education system since 1970 and the academic status of stakeholders. It is explained by the difficulty of physical education teachers to recognize the benefits they bring and the existence of a hierarchy between the importance given to the development of mind and body on the education system. This situation also exists in most Western countries despite theorizing of teaching physical education. It is only in cultures which gave pride of place to the body (Finland, Australia ...) that this type of complex physical education less or no mark at all.

Based on these results, we believe that physical education is still finding its place and its specificity. It must therefore fight to promote on several fronts: 
- Search the site and justify the level of general education;

- Take his autonomy from the sport, that is to say, to be recognized as a minority and no longer dependent discipline but free, independent and finally recognized ;

- Choosing specific and appropriate method.

\subsection{Second step: students}

We focused our attention on three themes: (1) attitudes toward school and during physical education; ( 2) perceptions of the physical education teacher and ; (3) the place of sport in everyday life .

\section{2. 1. The attitude}

(1) Attitude to School

Comparison by level of education and gender indicates that girls of the upper classes "like" more school than boys ( 8 out of 10 for girls and 6 of 10 for boys). These results are consistent with those reported in the literature (Piéron et al. 1998). They point to the more academically oriented girls who more likely to engage in studies than boys. This is often compared to the increasing feminization of intellectual professions where academic degrees are increasingly obtained by women. Moreover, the decrease in attitude depending on age is also usual in the sense that young people tend to deny that the obligation is school, do not understand the value of training or revolt against a system that forces them to work instead of engaging in more fun activities in their eyes.

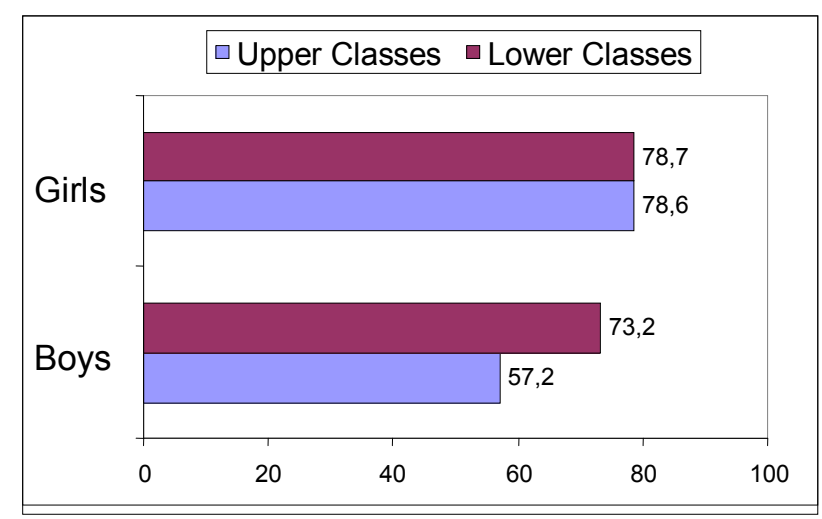

Figure (2): Attitudes toward the physical education classes at school

Unlike attitudes toward school, boys of different classes have a more favorable attitude to the current physical education than girls. The lowest percentage is $72.8 \%$ and is noted among girls of the upper classes (Figure 3). This difference is quite consistent with what is highlighted on an international scale (Cloes, Ledent \& Piéron, 2004).

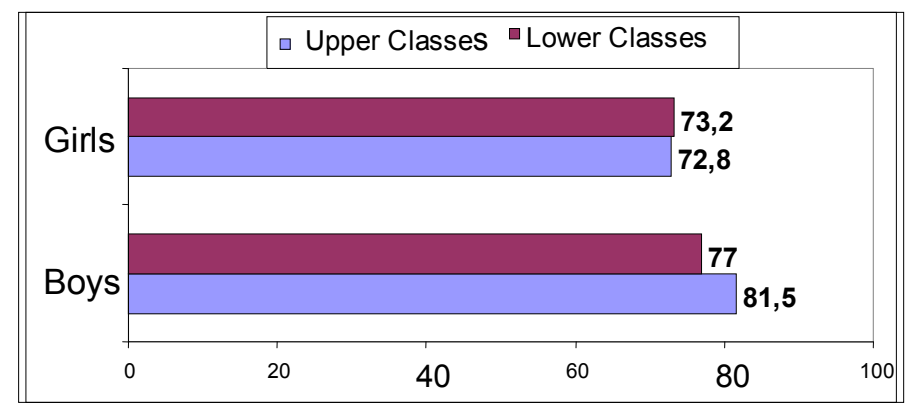

Figure 3. Percentage of students who "like" physical education (affective component)

With regard to the importance given to physical education, Algerian students also show very favorable in the sense that $73.7 \%$ of them believe that physical education is "very important" Overall, these results are similar to a study conducted in several European countries (Piéron, Ledent, Almond, Airston and Newberry, 1996) that researchers confirm that nearly nine out of ten students are in favor of the physical education.

It is possible that the preferred orientation courses in fitness and sports development that we have previously identified leads students to less awareness of the fundamental role of physical education for the overall development of the individual. This could also be linked to a lack of communication on the part of teachers who think more like coaches as educators, as is the case in other countries (Interuniversity Research Group, 2003). 
(3). Physical education objectives considered most important by students.

Taken together, the students think that school education continues as a priority to improve fitness. This objective significantly marks the surveyed population, confirming the views of teachers. Health occupies the second position in the hierarchy of objectives of school physical education ( Table 5). In this table, we see that the students have the same perception of the objectives of physical education as their teachers . This would emphasize that official guidelines are followed and assimilated by the different actors of the educational relationship .

Table 5. Objectives of physical education considered most important (\%)

\begin{tabular}{|l|l|l|l|l|}
\hline \multirow{2}{*}{ Physics } & \multicolumn{3}{|c|}{ Girls } \\
\cline { 2 - 6 } & \multirow{2}{*}{ High } & Low & High & Low \\
\hline Improve their condition & 50,5 & 34,8 & 26,1 & 30,3 \\
\hline Improve their look & 3 & 13,8 & 18,4 & 13,9 \\
\hline Enjoy and relax & 3 & 13 & 3,9 & 13,9 \\
\hline Foster social relationships ,make friends & & & & \\
\hline Reduce stress & 7,9 & 4,3 & 6,8 & 3,3 \\
\hline Learn sports & 2 & 1,4 & 1,9 & 1,6 \\
\hline Learn to respect rules & 9,9 & 5,8 & 5,8 & 6,6 \\
\hline Learn what to do manage health & 3 & 2,9 & 1,9 & 2,5 \\
\hline Learn what it takes to be active all his life & 11,9 & 21 & 20,4 & 23,8 \\
\hline
\end{tabular}

4. 2. 2. Perceptions of physical education teacher: The majority of students surveyed feel encouraged by their teachers. Another relevant point is that these students are strongly agree that their teachers have a active lifestyle. This finding is certainly due to the direct involvement of physical education teachers in the course. It is through gestures and personal physical effort that teachers learn from their students activities (Table 6).

Table 6: Students' perception regarding the behavior of their physical education teacher

\begin{tabular}{|l|l|}
\hline & $\mathbf{( \% )}$ \\
\hline Encourages you & 84,3 \\
\hline A......active life style & 73,1 \\
\hline ...Regularly participates in activities . & 70,3 \\
\hline ...Values you & 58,9 \\
\hline ...motivate you to participate in physical activities outside of school & 58 \\
\hline ...Information....you physical activities you can do outside of school & 57,3 \\
\hline ...You....explains the interest in physical activity out of school eg (club and associations) & 45,5 \\
\hline
\end{tabular}

\section{2. 3. Sports and Everyday Life}

The place of physical and sports activities (PSA) in the lives of Algerian students seem relatively small. Indeed, $13 \%$ of respondents reported practicing physical activities and sports outside school throughout the year and $29 \%$ for part of the year. In European countries, the proportion of active students is generally higher and between 60 and 70\% (Cloes, Ledent, Diniz, Didier \& Piéron, 1997). Algerian students could benefit from fewer opportunities to practice, highlighting the more fundamental role of physical education and also the need to consider a national sports policy more focused on promoting and organization of youth sports.

Algerian students often prefer to engage in physical activities and sports with friends, sometimes prefer to practice alone, and very rarely with the family. The boys practice more often and spend more time practicing than girls. They do more sport in sport clubs, alone or with friends. As in Western countries, this highlights the need to promote physical activity particularly among girls who represent a population at risk for inactivity and, in the longer term, in terms of diseases related to physical inactivity. Note also that the sport is more relevant for older students.

\section{Conclusion}

Analysis of perceptions of the objectives of physical education actors pedagogical relationship, we will retain the majority of teachers adhere to the official guidelines. Recent particular emphasis on sport as a phenomenon necessary for the physical and moral development, mobilization of citizens, the physical capacity building and improving the representation of the country in the international sports arena. These objectives are managed centrally by the Ministry of Education and Youth and Sports fashion. Representing how students of 
physical education and its objectives suffer the influence of teacher behavior and tasks it offers. We retain that physical education is well appreciated by all students to academic success.

Our study clearly showed that the majority of teachers consider the status of physical education as "lower" than other materials. This negative perception could be attributed to several factors such as the lower value to the note in physical education compared to other materials, the lack of resources and poor infrastructure. These factors have been proposed by the Algerian teachers to explain this inferiority. In this regard, Hardman (2001) points out that physical education has been pushed into a defensive position. She suffers from the shorter of the curriculum but also to insufficient financial resources.

This work has allowed us to pave the way for a major study focused on instructional strategies implemented by physical education teachers. This development will allow us to determine how teachers implement the physical education program on one side, and analyze interactive decisions of physical education teachers, on the other.

\section{References}

[1]. Arnaud, P. (1983). Les savoirs du corps. Lyon : Presses Universitaires.

[2]. Bailey, R. et Dismore, H. (nd). Le projet de sport dans l'éducation : examiner le rôle de l'éducation physique dans l'éducation. Le centre pour la recherche Educative, Canterbury Christchurch University College. Consulté le 16 janvier 2006 sur le site Web :http://66.249.93.104/search?q=cache:nGjJKmhKIG8J:spined.cant.ac.uk/documents/Le\%2520Projet\%2520de\%2520Sport\%25 20dans\%2520L.doc+\%22The+Sport+in+Education+Project +-+ SpinEd\%22\&hl=fr\&gl=be\&ct=clnk\&cd=1

[3]. Cloes, M., Ledent, M., Diniz, J., Didier, P., \& Piéron, M. (1997). Pratique et importance des principales activités de loisirs chez des jeunes de 12 et 15 ans dans cinq pays européens. Sport, 159/160, 51-60.

[4]. Cloes, M., Ledent, M., \& Piéron, M. (2004). Motiver pour éduquer, un éclairage qualitatif. In, G. Carlier (Dir.), Si l'on parlait du plaisir d'enseigner l'éducation physique. Montpellier : Editions AFRAPS. 65-73.

[5]. Delfosse, C., Ledent, M., Carriero da Costa, F., Telama, B., Almond, L., Cloes, M., et Piéron, M. (1997). Les attitudes de jeunes Européens à l'égard de l'école et du cours d'éducation physique. Sport, 159/160, 96-105.

[6]. Florence, J., Brunelle, J.P. \& Carlier, G. (1998). Enseigner l'éducation physique au secondaire. Motiver, aider à apprendre, vivre une relation éducative. Bruxelles : De Boeck Université.

[7]. Groupe de recherche interuniversitaire UCL-ULg sur l'Intervention dans les Activités physiques et sportives (2003). Adéquation entre les formations existantes en éducation physique, les motivations des étudiants et les différents débouchés professionnels. Le Point sur la Recherche en Education, 27, 29-57. Disponible aussi sur Internet : http://www.enseignement.be/@librairie/documents/ressources/088/synthese/article2002.pdf

[8]. Hardman, K. (2001). World-wide physical survey on the State and Status of Physical Education in schools, in G. Doll-Tepper \& D. Scoretz (eds). World Summit on Physical Education. Berlin: ICSSPE, pp. 15-36. Consulté le 16 janvier 2006 sur le site Web :http://66.249.93.104/search?q=cache:nGjJKmhKIG8J:spined.cant.ac.uk/documents/Le\%2520Projet\%2520de\%2520Sport\%25 20dans\%2520L.doc $+\% 22$ The + Sport + in + Education + Project +-+ SpinEd $\% 22 \& h l=$ fr $\&$ gl $=$ be $\& c t=$ clnk \&cd $=1$

[9]. Ministère de la Jeunesse et des Sports (1995). Ordonnance, 95-09. Alger.

[10]. Ministère de la Jeunesse et des Sports (1970). Instruction Officielles. Algérie: Organisation de l'enseignement de 1'Education Physique.

[11]. Ministère de l'Education Nationale (1976). Algérie : Bulletin Officiel de l'Education Nationale.

[12]. Ministère de l'Education Nationale (1996). Algérie : Objectifs de l'EP, dans L'enseignement moyen et secondaire.

[13]. Pate, R., Davis, M., Robinson, T., Stone, E., McKenzie, T. \& Young, J. (2006). Promoting Physical Activity in Children and Youth: A Leadership Role for Schools: A scientific Statement From the American Hearth Association Council on Nutrition, Physical Activity, and Metabolism (Physical Activity Committee) in collaboration with the Councils on Cardiovascular Disease in the Young and Cardiovascular Nursing. Circulation, 114, 1214-1224.

[14]. Piéron, M., Cloes, M., Delfosse, C., \& Ledent, M. (1996). An investigation of the effects of daily physical education in Kindergatend and elementary schools. European Physical Education Review, 2, 2, 116-132.

[15]. Piéron, M., Cloes, M., Luts, K., Ledent, M., Pirottin, V., \& Delfosse, C. (1998). Analyse de la prise en considération des caractéristiques individuelles des élèves dans les décisions et les comportements d'enseignants experts et débutants. Rapport final (enseignement primaire et secondaire) d'une recherche réalisée dans le cadre d'une convention passée entre la Communauté française de Belgique et l'Université de Liège (157/96). Disponible également sur Internet: http://www.enseignement.be/@librairie/documents/ressources/157/rapport final.pdf

[16]. Piéron, M., Ledent, M., Almond, L., Airstone, M., et Newberry, I. (1996). Comparative analysis of youth lifestyle in selected European countries University of Liège et University of loughborough. Recherche commanditée par l' "International Council of Sport Science and Physical Education ».

[17]. Stat Soft. (2006). Statistica 7.1. Compus « étudiant» 2006. Version 7.1 F2. Maisons-Afort : Stat Soft.

[18]. Tappe, M.K. \& Burgeson, C.R. (2004). Physical Education: A Cornerstone for Physically Active Lifestyles. Journal of Teaching in Physical Education, 23, 4, 281-299.

[19]. Thibault, J. (1977). Les aventures du corps de la pédagogie française : étude historique et critique. Paris : Ed. Vrin.

[20]. Thomas, R. (1982). L'éducation physique. Paris: Ed. P.U.F

[21]. WHO (2006). Obesity in Europe. Retrieved from Internet on April 2, 2006: http://www.euro.who.int/obesity 